\title{
Nova direita? \\ Guerras de memória em tempos \\ de Comissão da Verdade (2012-2014)
}

\section{The New Right? War of Memories in Times \\ of Comissão da Verdade in Brazil (2012-2014)}

Mateus Henrique de Faria Pereira

Departamento de História

Universidade Federal de Ouro Preto

Rua do Seminário, s/n, Mariana, MG, 35.420-000, Brasil

matteuspereira@gmail.com

Resumo Este ensaio aborda os possíveis efeitos indiretos e não previstos da presença da Comissão Nacional da Verdade (2012-2014). Tendo em vista o jogo entre inscrição e não inscrição, procuraremos recuperar algumas guerras de memórias e imagens que circularam e aconteceram na internet. Concluímos que, durante esse período, ocorreram ao mesmo tempo dois processos contraditórios: um aumento da negação e/ou revisionismo em relação ao último período autoritário e o desenvolvimento de uma inscrição frágil. Busca-se, assim, compreender melhor as estruturas, as permanências e as dissimulações de práticas, lógicas e pensamentos de matizes autoritários no Brasil.

Palavras-Chave tempo presente, ética, usos do passado

Recebido: 3 de agosto de 2015 | Aprovado: 6 de setembro de 2015

http://dx.doi.org/10.1590/0104-87752015000300008

Varia Historia, Belo Horizonte, vol. 31, n. 57, p. 863-902, set/dez 2015 
Abstract This essay focuses on possible unanticipated and indirect effects of the presence of the Comissão da Verdade in Brazil (20122014). Considering the interplay between markings and non-markings we will seek to recover some war of memories and images that circulated and happened on the internet. We conclude that during such period occurred at the same time two contradictory processes: increased negation and/or revisionism over the last authoritative period and the development of a faint markings. The aim is to thus better understand the structures, the permanencies and the dissimulations practices, logics and thinking shades authoritarian in Brazil.

KEYWORDs present time, ethical, uses of the past

Tuas idéias não correspondem aos fatos

(Cazuza. O tempo não pára, 1988).

Desde 1964, diversas batalhas de memória sobre o Golpe Civil-Militar de 1964 e, posteriormente, sobre a Ditadura Militar brasileira (19641985) foram travadas. Entretanto, muitas dessas entraram em latência e emergiram de diversos modos nos últimos anos, em particular entre 2012 e 2014. Este ensaio parte de um caso ocorrido em 2012 na página de discussão do verbete "Regime militar brasileiro" (em português) da Wikipédia, logo, ao mesmo tempo em que se iniciavam os trabalhos da Comissão Nacional da Verdade - fonte de estímulo para centenas de Comissões da Verdade que trabalharam em âmbitos estaduais, municipais e setoriais -, que procurou, até fins de 2014, investigar violações de direitos humanos daquele período, ainda que sem poder de punição. Nossa intenção não é, assim, analisar diretamente os trabalhos dessa Comissão, mas utilizar o período de sua atuação para recortar o tempo e, também, para verificar alguns possíveis impactos indiretos de sua presença.

Com base no caso citado, nosso objetivo neste ensaio é compreender melhor alguns aspectos específicos da presença do discurso negacionista, da negação e do revisionismo, bem como as estratégias de combate a 
eles no espaço público brasileiro contemporâneo, levando-se em consideração alguns textos e imagens específicos que circularam e estiveram disponíveis na internet ao longo desses dois anos. Afinal, reconstruir uma batalha pela/de memória não é suficiente, bem como fazer apenas $o$ restabelecimento dos fatos. É preciso interrogar como uma determinada concepção sobre o que ocorreu anteriormente se cristalizou ou se construiu, o que isso significa e a que serve (Portelli, 2005, p.18). Recolocamos e ampliamos, assim, em nosso contexto, questões já propostas por Pierre Vidal-Naquet (1994): quem são os nossos "assassinos da memória"? A que servem? São produtos e produtores de qual mundo? Porém, o que significa pensar essas questões com base nas premissas de que não há uma oposição ou mesmo uma ruptura entre memória e esquecimento, entre passado e presente, entre objetividade e subjetividade, entre história e memória?

Nossa primeira hipótese é que o revisionismo e a negação brasileira são alimentados, em grande medida, pela impunidade (ausência de justiça, muito em função da permanência da Lei da Anistia) e pela ausência de arrependimento, remorso ou culpa por parte dos algozes diretos e indiretos e dos apoiadores de ontem e de hoje. Ainda que o primeiro aspecto esteja presente, destacaremos mais esse último fator.

Nossa segunda hipótese é que talvez estejamos assistindo hoje, no Brasil, à passagem de um "clima" ou "regime" de "não inscrição" para um "clima" ou "regime" de "inscrição frágil". Porém, essa passagem "sutil" e "etérea" não tem necessariamente levado à transformação da "memória dividida" em uma "memória compartilhada". Tal complexidade nos leva, assim, a refletir sobre algumas das ambiguidades e dos desafios éticos e políticos do trabalho de memória e de história.

Os conceitos centrais serão trabalhados ao longo do texto. Ainda assim, como ponto de partida, apresentamos alguns dos sentidos que atribuímos a eles. Inscrição: marca, selo, cicatriz, elaboração, sobrevivência, persistência, permanência, impressão e fixação. Não inscrição: sombra, branco, vazio, nevoeiro, apagamento, repressão, invisibilidade e silenciamento. Negação: contestação da realidade, fato ou acontecimento que pode levar à dissimulação, à falsificação, à fantasia, à distorção e ao 
embaralhamento. Em geral, percebemos uma dissimulação e uma distorção da factualidade que, ou procura negar o poder de veto das fontes, ou fabrica uma retórica com base em "provas" imaginárias e/ou discutíveis/ manipuladas. Revisionismo: interpretação livre que não nega necessariamente os fatos, mas que os instrumentaliza para justificar os combates políticos do presente a fim de construir uma narrativa "alternativa" que, de algum modo, legitima certas dominações e violências. Negacionismo: radicalização da negação e/ou do revisionismo. Falsificação do fato.

\section{RUMORES - PARTE I}

Pesquisando nos arquivos da Wikipédia encontramos uma discussão interessante que será aqui utilizada como uma escala inicial, como ponto de partida para operarmos o princípio de variação de escalas (Revel, 1998). Essa escala inicial é considerada aqui como um caso, entendido como algo que traz um problema, que conclama uma solução e possibilita uma nova reflexão, novos desdobramentos (Passeron; Revel, 2005). O caso em questão ocorreu no ano de 2012, na página de discussão do verbete "Regime militar no Brasil".

Em 21 de junho de 2012, um dos colaboradores, registrado como "Gutim", afirmava:

não tenho fontes altamente fiáveis para fazer o que pretendo, mas vou esclarecer o que é. Já li e ouvi os pareceres de muitos esquerdistas e direitistas acerca do governo Castelo Branco. O mais comum é que o referido governo foi o melhor da época que antecedeu o endurecimento da ditadura militar. [...]. Afinal, por estas fontes que não posso usar, concluo que o Brasil poderia facilmente ter tido um Presidente eleito democraticamente um ano e meio do Golpe de 1964. Por estas razões, se tivesse como fiáveis estas fontes, eu adicionaria ao artigo. (Disponível em: http://pt.wikipedia.org/w/index.php?title=Discuss\%C3\%A3o:Regime_militar_no_Brasil\&oldid=35603996; Acesso em: 10 abr. 2013. Todas as transcrições ao longo do nosso texto mantêm a grafia, a ortografia e eventuais erros dos originais) 
Percebem-se, pelos nossos itálicos na citação acima, as dimensões das normas definidas pelos colaboradores da Wikipédia para a análise e utilização de fontes. Elas prezam, por exemplo, pela "imparcialidade" e "verificabilidade". Essas regras interditam a utilização do testemunho oral que não possa ser objeto de crítica e/ou verificabilidade, como se atesta na citação em questão. Rosenzweig (2011) destaca que a ideia de imparcialidade (ou, diríamos, o desejo de imparcialidade) fornece uma base discursiva compartilhada entre os colaboradores. Ainda, segundo o autor, dado seu modo coletivo e a política de neutralidade, ela tende a evitar afirmações polêmicas, interpretações sensacionalistas e teorias de conspiração. A obediência a essas regras cria um "filtro", como vemos na hesitação do colaborador em escrever que o "governo Castelo Branco" "foi o melhor da época que antecedeu o endurecimento". Mesmo que talvez o faça de forma ingênua (por exemplo, quando afirma "se Castelo Branco" "tivesse tomado as medidas certas"), cabe destacar que o autor aborda um tema discutido pela historiografia contemporânea: a transformação do golpe civil-militar em uma ditadura. ${ }^{1}$ Como veremos no próximo exemplo, a política da "imparcialidade" e "verificabilidade" implica debates acalorados e polêmicos na seção "discussão".

Em 25 de agosto de 2012, outro colaborador, registrado como "Tigre do Oeste", afirmava que seu desejo era pôr fim à "guerra de edições" em uma parte da narrativa sobre a relação entre guerrilhas e abertura política. $\mathrm{O}$ autor não altera o texto anterior, mas acrescenta as sentenças que estão em itálico:

concomitantemente a uma tímida abertura política, no governo Geisel, as guerrilhas acabaram perdendo força. Isso também se deveu a operações repressivas governamentais que visavam eliminar a oposição (fosse armada ou não), que envolvia a execução de militantes de esquerda e guerrilheiros, sendo o mais conhecido o massacre da Guerrilha do Araguaia, ocorrido entre 1973 e 1974. Em entrevista à revista IstoÉ, concedida no

1 Entrevista de Carlos Fico no Café História TV, 2014. Disponível em: https://www.youtube. com/watch?v=Dm6J7kc3DBc; Acesso em: 16 nov. 2014. 
ano de 2004, um general afirmou que, concluiu-se em 1973 que "ou se matava todo mundo ou essas guerrilhas nunca mais teriam fim. (Disponível em: http://pt.wikipedia.org/w/index.php?title=Discuss\%C3\%A3o:Regime_militar_no_Brasil\&oldid=35603996; Acesso em: 10 abr. 2013)

Destacamos que a "guerra de edições" pôde se "encerrar" não pela mudança de sentido, mas, sobretudo, pela inserção da "prova", isto é, pela referência a um artigo publicado pelo jornalista Amaury Ribeiro Júnior em 2004 na Revista IstoÉ e pela citação de um depoimento de um general na mesma revista no final da última e da penúltima frase. Caso o leitor clique em um link das notas ele terá, em tese, acesso direto à página da revista utilizada disponível on-line. Dois dias depois, outro usuário, desta vez não identificado com um pseudônimo ou um nome, mas pelo código IP, o endereço de cada computador na internet, “189.78.72.125”, afirmava que apresentaria uma denúncia nos seguintes termos:

Sr. Comandante do Exército: há 5 anos, um cidadão residente do Rio Grande do Sul, que usa o pseudônimo de "Tigre do Oeste" usa a enciclopédia livre Wikipédia, na sua versão em português, para, em artigos relacionados ao exército brasileiro, presidentes da republica e outros artigos relacionados a militares, difamar, caluniar e imputar falsos crimes ao exército brasileiro e fazer apologia ao terrorismo no Brasil ocorrido nas décadas de 1960 e 1970, tentando justificar as mortes bárbaras de soldados brasileiros como a do Soldado Mário Kozel Filho. O Comando Militar do Sul já o monitora apenas. (Disponível em: http://pt.wikipedia.org/w/index.php?title=Discuss\%C3\%A3o:Regime_militar_no_Brasil\&oldid=35603996; Acesso em: 10 abr. 2013).

Assim, para o IP “189.78.72.125”, Tigre do Oeste é calunioso, pois imputa falsos crimes aos militares. Além disso, faz apologia ao "terrorismo" ocorrido no Brasil na década de 1960 e 1970 e, por consequência, justifica mortes bárbaras de soldados. A reação de Tigre do Oeste é sarcástica: "que tal se aconselhar com um psicólogo?". Ele também coloca em dúvida se o IP é de uma só pessoa ou de um conjunto de 
pessoas que estariam "vigiando" a produção desse tipo de conteúdo. A batalha se encerra aí.

O que desejamos destacar é que os trechos citados - em especial o do conflito entre o usuário "Tigre do Oeste" e o usuário de IP “189.78.72.125" - revelam aspectos da "guerra de memória" sobre a Ditadura Militar nas suas inter-relações entre o "virtual", o "atual" e o "real". Essa ênfase no conflito permite refletir sobre a internet como um "veículo de memória", em especial por trazer os conflitos de/pela(s) memória(s) para o espaço público: "não existem 'guerras de memórias' sem que se coloque a questão da transmissão (silenciada ou esquecida) e da mediação, isto é, da midiatização (em sentido amplo)" (Blanchard; Veyrat-Masson, 2008, p.21). As guerras de memórias pressupõem a visibilidade que a mídia pode agregar ao debate público. Trata-se, em geral, de interrogações do presente sobre violências de um determinado "passado-presente" (Huyssen, 2014). As guerras de memória nos convidam a empreendermos uma "analítica" sobre as estreitas e complexas relações entre a mídia e historicidade (Ferro, 2008; Araujo, 2013). Desse modo, pretendemos deslocar a discussão sobre a oposição e/ou articulação entre memória e história para a metáfora da guerra.

Os conflitos (tomados por intermédio da metáfora da guerra) de/pela memória no movimento da Wikipédia (e de muitos sites consultados) não podem ser vistos apenas como expressão de opiniões particulares, pois são produzidos e/ou regulados por meio de dispositivos construídos pelos colaboradores (D’Andréa, 2011; Johnson, 2009). E o historiador, como deve agir diante de discursos que rejeitam, negam, justificam, superdimensionam e/ou interpretam livremente a factualidade do que ocorreu anteriormente? Para Paul Ricoeur (2007, p.190), “o fato não é o acontecimento, ele próprio devolvido à vida de uma consciência testemunha, mas o conteúdo de um enunciado que visa representá-lo”. O autor ainda destaca que:

Essa reciprocidade entre a construção (pelo procedimento documental complexo) e o estabelecimento do fato (com base no documento) exprime o estatuto epistemológico específico do fato histórico. É esse 
caráter proposicional do fato (no sentido de fato de que) que rege a modalidade de verdade ou de falsidade ligada ao fato. Nesse nível, os termos verdadeiro/falso podem ser tomados de maneira legítima no sentido popperiano do refutável e do verificável. É verdadeiro ou é falso que em Auschwitz foram utilizadas câmaras de gás para matar tantos judeus, poloneses, ciganos. É nesse nível que se decide a refutação do negacionismo. Por isso era importante delimitar corretamente esse nível. Com efeito, essa qualificação veritativa da "prova documental" não será encontrada nos níveis da explicação e da representação, nos quais o sentido popperiano de verdade se tornará cada vez mais difícil de aplicar (Grifo nosso).

Como pretendemos demonstrar ao longo do texto, a "guerra de memória" aqui tratada não é um conflito dicotômico ou maniqueísta entre o bem e o mal ou, apenas, entre duas partes. Concordamos que "estamos lidando com uma multiplicidade de memórias fragmentadas e internamente divididas, todas, de uma forma ou de outra, ideológica e culturalmente mediadas" (Portelli, 2000, p.107). Multiplicidade não só de memórias, mas também de historiografias e temporalidades. Nessa direção, Roberto Vecchi lança algumas indagações que pretendemos explorar: "qual é a ética necessária para usar a memória sem cair nas armadilhas do revisionismo, numa palavra, como representar a barbárie, apesar de todas as aporias miméticas, para fundar a sua memória?" (2001, p.87-88).

\section{RUMORES E ECOS - PARTE II}

A estrutura temporal da negação e, em alguma medida, do revisionismo, está assentada numa concepção fatalista, determinista e homogênea do tempo histórico. Uma determinada concepção de tempo homogênea tende a afirmar que o Golpe de 1964 só existiu porque não havia outra alternativa; ele foi inevitável. Se não fosse o Golpe, teria havido um golpe e uma ditadura comunista. Os militares salvaram o Brasil dos terroristas e comunistas, pois agiram antes. O golpe foi, na verdade, uma 
"contrarrevolução". Esse tipo de argumento fundamenta-se naquilo que Vidal-Naquet chama de "revisionismos relativos". Na internet encontramos inúmeras manifestações a esse respeito.

Para os nossos propósitos convém destacar a página on-line da "enciclopédia alternativa" Metapédia. Ela tem se destacado por abrigar diversos verbetes negacionistas e revisionistas no sentido de contrariar as evidências básicas da pesquisa histórica e da memória (Noiret, 2015, p.40). O interessante é que essa enciclopédia usa a mesma forma da Wikipédia, isto é, o sistema Wiki, para apresentar o que chama de "interpretações próprias" dos fatos. A apropriação livre da forma da Wikipédia, portanto, cria um simulacro de verdade a fim de legitimar uma intenção de mentira, abusos e distorções de memória. Na Metapédia, por exemplo, não existe o verbete Golpe Militar e sim “contra-revolução", onde se lê:

O Contra-golpe de 1964 (como é chamado pelos militares) ou Golpe militar de 1964 foi uma ação bem-sucedida efectuada pelo exército que supostamente tinha a finalidade de afastar o perigo do comunismo no Brasil. No entanto, a CIA e os Estados Unidos da América estavam por trás deste acontecimento, já que segundo eles, terroristas de esquerda queriam tomar o controle do país e o transformar em uma espécie de Cuba com influência soviética. Os militares agiram para evitar uma possível invasão militar estadunidense no Brasil e reprimiram os comunistas durante o período em que o Regime Militar esteve ao poder, entre 1964 e 1984 (Disponível em: http://pt.metapedia.org/m/index.php?title=Contra-golpe_de_1964\&oldid=18988; Acesso em: 15 abr. 2014).

Segundo o texto, a responsabilidade do "contra-golpe" ou do "golpe" não pode ser atribuída aos militares e sim aos Estados Unidos. Os militares agiram para evitar uma possível invasão militar estadunidense e "reprimiram os comunistas" durante a Ditadura Militar. Trata-se, antes de tudo, de dissimulação, manipulação e justificação, pois se sabe, por exemplo, que os militares agiram cientes do apoio americano e não para evitar uma invasão militar (Fico, 2008). O verbete "Regime Militar" também retira responsabilidades dos militares. Segundo ele, o "regime" 
foi na verdade "um governo fantoche anti-comunista instalado pela CIA no Brasil em plena Guerra Fria. ${ }^{2}$ O Golpe e a Ditadura são, assim, eventos "externos" ao Exército e à sociedade. ${ }^{3}$

Cabe destacar que não há, em nossa análise, uma distinção radical entre revisionismo e negacionismo, especialmente em sua dimensão psicológica e ideológica (como destacaremos no próximo tópico): “una práctica revisionista fundamental consiste em negarse a distinguir entre las palabras y la realidad" (Vidal-Naquet, 1994, p.119, grifo nosso). O revisionismo "absoluto" é, em grande medida, um tipo de "negacionismo" puro ou literal. A esse respeito, Vidal-Naquet afirma: "hablo aqui del 'revisionismo' en el sentido absoluto del término, aunque existen también revisionismos relativos". O autor destaca que a palavra revisionismo adquiriu, ao longo da história, um sentido ora positivo, ora negativo, "implicando siempre la crítica de una ortodoxia dominante" (1994, p.106). No entanto, Vidal-Naquet adverte que "por definición, el historiador vive en lo relativo, y es seguramente eso lo dificulta tanto la aprehensión del discurso revisionista" (1994, p.133).

Em uma linha próxima, mas mais radical, Rancière, em Os nomes da história, afirma que toda história está fadada ao revisionismo, que pode ser pensado por meio da fórmula "não aconteceu nada daquilo que foi dito" (apud Ricoeur, 2007, p.356). Assim, os diversos revisionismos não se reduzem ao que é escrito, pois são nutridos por argumentos teóricos e paixões plurais. "O coração da demonstração revisionista é sempre uma estratégia discursiva que consiste em esmigalhar um evento - a revolução francesa, o genocídio nazista, entre outros - numa profusão de fatos para constatar, em contrapartida, que, somados uns aos outros, não faz nunca a lógica de um encadeamento rigoroso a partir de uma causa primeira até às últimas conseqüências" (Rancière, 2005).

2 Disponível em: http://pt.metapedia.org/m/index.php?title=Regime_militar_no_Brasil\&oldid=20521; Acesso em: 15 abr. 2014.

3 Ver também, o vídeo “O contragolpe de 1964 - A Verdade Sufocada”. Disponível em: https:// www.youtube.com/watch?v=XGwYHMuZn60; Acesso em: 14 ago. 2015; e Olavo de Carvalho - 1964: 50 anos do contra-golpe. Disponível em: https://www.youtube.com/watch?v=qKquKjm_PJE; Acesso em: 14 ago. 2015. 
De algum modo, as manifestações de algo próximo a um "negacionismo puro", entre 2012-2014, consistiram em mostrar que a tortura foi um "excesso" e não uma política de Estado: "A tortura nunca foi estimulada, consentida ou praticada pelos "ditadores" militares". ${ }^{4}$ Do fato à interpretação: estamos, assim, em nosso percurso, diante da questão dos limites da interpretação e da representação. A tensão e certa interdependência dos conceitos de negação (e não necessariamente de negacionismo) e revisionismo se apresentam em toda a nossa investigação. Em certo sentido, o conceito de contragolpe é um tipo de revisionismo, mas pode ser tomado também como uma negação à conceituação dada ao golpe pelos próprios militares. Não custa retomar algumas passagens do preâmbulo do AI-1, de 1964: "o que houve e continuará a haver neste momento, não só no espírito e no comportamento das classes armadas, como na opinião pública nacional, é uma autêntica revolução. [...] Assim, a revolução vitoriosa, como Poder Constituinte, se legitima por si mesma". Conforme lembra Daniel Faria, o ato institucional não estava previsto na constituição de 1946. Uma contra-revolução, isto é, a restauração de uma ordem constituída, não permitiria a introdução da figura dos atos institucionais. O autor do preâmbulo, Francisco Campos, resolve a questão com base na ideia do poder revolucionário.

Ironicamente, podemos dizer que os defensores da ideia de contra -revolução criam, assim, um embaraço, uma contradição e uma dissimulação, na medida em que, se o golpe foi uma contra-revolução, ele não tinha nenhuma "legitimidade" para outorgar atos institucionais, com todas as consequências dos 17 atos que viriam a ser decretados entre 1964 e 1969. Se tivesse ocorrido uma contra-revolução o governo seria ilegítimo, logo, no interior da tradição liberal fundamentada em John Locke, seriam legítimas a luta armada e a guerra civil. Nessa perspectiva, a resistência, inclusive a violenta, seria um direito (Saflate, 2010).

4 Disponível em: http://www.ternuma.com.br/index.php/revanchismo/14-revanchismo/12copia-da-carta-enviada-a-jornalista-miriam-leitao-de-o-globo; Acesso em: 17 ago. 2015. Ver também: http://www.averdadesufocada.com; http://www.grupoinconfidencia.org.br/sistema; https://liciomaciel.wordpress.com; Acesso em: 17 ago. 2015. 
No que se refere à correta utilização do conceito de golpe convém destacar, dentre outros fatores, um aspecto factual. Trata-se da vacância da presidência. Ainda hoje muitos atribuem a suposta fuga de João Goulart para o Uruguai como a razão para a decretação da vacância pelo presidente da Câmara, Ranieri Mazzili. Esse tipo de "versão" é desmentida pelos fatos e legitima o golpe. Na verdade, a vacância anunciada em $1^{\circ}$ de abril de 1964 foi inconstitucional na medida em que João Goulart permaneceu no país até o dia 4 de abril de 1964. Ainda que se possam refutar certas abordagens factuais dos discursos revisionistas e negacionistas, é possível desconstruí-los e bloqueá-los por completo? Qual o lugar da historiografia nesse processo? Mediar e qualificar?

\section{RUMORES E ECOS - PARTE III}

Freud, no texto "Verneinung" (1925), traduzido recentemente como "A negação" (há traduções que preferem "A negativa” ou "A denegação"), sugere um experimento interessante para entendermos a negação: "tomamos a liberdade, na interpretação, de ignorar a negação e apenas extrair o conteúdo da ideia" (Freud, 2012, p.250). A fim de deixar mais claro o que se está chamando aqui de negação, propomos um exercício limite para extrairmos o conteúdo da ideia. Em 13 de agosto de 2014, o Ministério da Defesa apresentou o Ofício n 10.944 e três anexos com as conclusões das sindicâncias promovidas para apurar desvios de finalidade no uso de instalações militares entre 1945-1988 (período de investigação da Comissão da Verdade). ${ }^{5}$

A seguir citaremos todos os trechos em que o advérbio de negação não aparece, porém colocaremos intencionalmente o não original em itálico e entre parênteses. A ideia é que o leitor possa ler o texto suprimindo o não, a fim de verificar se há a lógica da negação, pelo menos no sentido freudiano.

5 Disponíveis em: http://www.cnv.gov.br/images/pdf/Defesa_FFAA_esclarecimentos_2014_09_19. pdf; Acesso em: 01 set. 2014. 
Ofício do Ministério da Defesa assinado por Celso Amorim, ministro da Defesa:

O Ministério da Defesa, como parte integrante do Estado Brasileiro, compartilha do reconhecimento da responsabilidade estatal pela ocorrência de graves violações de direitos humanos praticadas no período de 18 de setembro de 1946 a 05 de outubro de 1988. Nesse sentido, observo que as conclusões dos ofícios dos Comandos Militares (não) se contrapõem a esse reconhecimento.

Ofício do Exército assinado por Enzo Martins Peri, comandante do Exército:

os dados disponíveis (não) permitem corroborar a tese apresentada por aquela Comissão de que tenha ocorrido desvio formal de finalidade do fim público estabelecido para as instalações objeto da investigação", (não) havendo, desta forma, fato novo que modifique tal percepção. Por fim este Comando entende que (não) lhe é pertinente manifestar-se a respeito de atos formais e de outras decisões tomadas pelo Estado Brasileiro ou, ainda, opinar sobre situações já definidas pelo ordenamento jurídico vigente;

Ofício da Aeronáutica assinado por Juniti Saito, comandante da Aeronáutica:

sobre a conclusão da sindicância a que se refere a Comissão Nacional da Verdade (CNV), informo a Vossa 'Excelência que o Comando' da Aeronáutica lançou mão de pesquisa em documentos históricos existentes, (não) dispondo de outras informações que possam corroborar as conclusões apresentadas pela CNV. Da mesma forma, o Comando da Aeronáutica também ( não) dispõe de elementos que sirvam de fundamento para contestar os atos formais de reconhecimento da responsabilidade do Estado brasileiro. 
Ofício da Marinha assinado por Carlos Augusto de Sousa, comandante interino da Marinha, e por José Martins Cavalcante, encarregado da Divisão de Secretaria e Comunicações:

Em atenção ao Ofício [...] os trabalhos levados a termo pela Sindicância administrativa realizada, (não) foram encontrados indícios nem provas documentais ou materiais que permitam confirmar ou negar as informações [...].

Cairíamos num psicologismo simplista se disséssemos que a suspensão de todos os advérbios de negação (não) revela uma realidade reprimida ou escondida. Mas a abundância de seu uso ao menos indica que há, por um lado, uma dificuldade de aceitar a realidade com todas as suas possíveis consequências e, por outro, que há muito cuidado em não desmentir (afinal, é dito que não se pode "confirmar ou negar as informações"), o que talvez demonstre certa tomada de consciência do que se passou. Cito o trecho menos ambíguo a esse respeito: "da mesma forma, o Comando da Aeronáutica também não dispõe de elementos que sirvam de fundamento para contestar os atos formais de reconhecimento da responsabilidade do Estado brasileiro". Ou seja, há elementos de tomada de consciência, mas o abuso da negação pode denotar exatamente uma dificuldade institucional, um não querer aceitar e arcar com as consequências dessa aceitação.

Além disso, é preciso dizer que em boa medida o ofício assinado pelo ministro da Defesa destoa dos outros. Tanto é que o especial "ditabranda", do site DefesaNet, de 21 de setembro de 2014, afirma: "Amorim desconsidera Ofícios dos Comandantes e endossa acusações às Forças Armadas pela Comissão Nacional da Fantasia Ideológica, também conhecida como Comissão Nacional da Verdade". ${ }^{6}$

No entanto, é provável, dentro da perspectiva freudiana (da negação e não necessariamente do negacionismo), que a maioria dos trechos

6 Disponível em: http://www.defesanet.com.br/dita/noticia/16876/CNV---Oficios-do-MD--EB---FAB---MB-/; Acesso em: 03 abr. 2015. 
marcados indique que não há uma aceitação intelectual que leve a uma aceitação afetiva do erro, por exemplo, pela culpa, pelo remorso e/ou pelo arrependimento: "nisso vemos como a função intelectual se separa do processo afetivo"? Essa espécie de aceitação intelectual do reprimido mantém, portanto, o essencial: "negar algo num juízo é dizer, no fundo: 'isso é algo que eu gostaria de reprimir"' (Freud, 2012, p.251). Tudo foi feito em nome de um fim maior: livrar o país da ameaça comunista!

Para Freud, a função do juízo na negação tem como propósito admitir ou contestar uma representação com existência na realidade: "o não real, apenas representado, subjetivo, está apenas dentro; o outro, o real, também se acha fora" (Freud, 2012, p.252). Nessa perspectiva, para se reprimir, silenciar, falsear ou esquecer é preciso contestar a realidade do que se passou durante a Ditadura Militar brasileira não necessariamente pela mentira, mas pela negação e também pelo revisionismo, que distorcem e justificam os crimes e o estado de exceção. Em grande medida são, portanto, discursos e narrativas que justificam práticas, lógicas e ideologias que permanecem e/ou aceitam o inaceitável.

Nessa direção, em seu sentido psicológico, a negação, posta em destaque por nós, deve ser vista em relação aos outros "mecanismos de defesa", com destaque para a repressão, a racionalização, a formação reativa, a projeção, a regressão e a sublimação. Afinal, dentro (e fora) da "Razão de Estado", ontem (e ainda hoje) era (e é) possível justificar o injustificável: tortura e assassinatos. ${ }^{8}$ Considerando-se o referente extralinguístico da negação aqui analisada, podemos perguntar: até que ponto um enunciado negativo partilha o mesmo significado do enunciado afirmativo correspondente? Nessa direção, qual é o limite do nosso experimento? Para Virno, "o enunciado negativo abre estrada para a dissimulação", no entanto, "a capacidade de dissimular uma paixão implica sempre a capacidade, oposta e especular, de simular" (Virno, 2013, p.148, grifo no original).

7 FREUD, 2012, p.251. Sobre a questão da culpa ver JASPERS, 1990.

8 Sobre a relação entre irreparável, imprescritível e imperdoável, ver MARANHÃO; PEREIRA, 2011. 
Assim, a poliformia da negação brasileira não é apenas uma negação inconsciente, nos termos analisados por Freud. A negação brasileira é, também, uma negação linguística, pública e ideológica. Ela ultrapassa, portanto, a questão do negacionismo, do revisionismo e da negação freudiana. Quais afetos a nossa negação e revisão da história representam e estimulam? À qual integração identitária ela serve? Há alguma lógica tradicionalista, ou mesmo fundamentalista em relação a certas leituras daquele tempo? É em busca de boas respostas para essas perguntas que passamos para os próximos tópicos.

\section{RUMORES - PARTE IV}

O autoritarismo é, também, um tipo de negação ideológica: “as ideologias autoritárias, enfim, são ideologias que negam de uma maneira mais ou menos decisiva a igualdade dos homens e colocam em destaque o princípio hierárquico" (Bobbio; Mateucci; Pasquino, 2004, p.94) No entanto, do ponto de vista da ideologia, a análise da negação e do revisionismo desemboca no paradoxo da ideologia: haveria uma instância crítica capaz de colocar em distância o fenômeno da ideologia? Como escapar desse paradoxo? (Ricoeur, 1986; 1997).

Tendo em vista essas questões e as do último item, destacamos abaixo uma imagem reveladora do revisionismo (que, em certa medida, é também um trabalho de negação psicológica e ideológica):

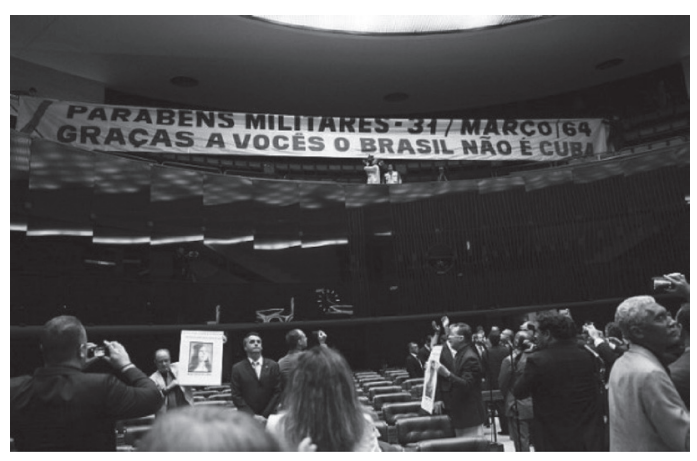

Imagem 1: "Parabéns militares”, abr. 2014. Disponível em: http://www.pragmatismopolitico.com.br/wp-content/uploads/2014/04/parabens-militares.jpg; Acesso em: 04 maio 2014. 
Não é fortuito que essa faixa, presente como um passageiro clandestino na seção solene da Câmara dos Deputados para relembrar os 50 anos do Golpe de 1964, destacasse que graças aos militares o Brasil não era Cuba. Provavelmente, a faixa foi estendida a mando do militar reformado e deputado fluminense Jair Bolsonaro (de terno escuro, de frente, à esquerda na imagem acima), que seis meses depois seria eleito o deputado federal mais votado do Rio de Janeiro, com quase $500 \mathrm{mil}$ votos. Diga-se de passagem, uma foto do deputado com essa faixa é a capa de seu site. ${ }^{9}$

Levando em conta esse rumor e a análise anterior, podemos dizer que a negação, em seu sentido ideológico, bem como o revisionismo, em seu sentido absoluto e relativo, está intimamente ligada àquilo que Ricoeur chama de abuso de memória e de esquecimento, em particular, de memória manipulada. ${ }^{10} \mathrm{O}$ processo ideológico está ligado aos combates e às denúncias contra os adversários no interior da competição entre ideologias. Assim, a distorção imagética deve ser articulada com o fenômeno de legitimação e da mediação simbólica. A compreensão dessas dimensões intermediárias pode nos permitir entender a negação e o revisionismo brasileiro como "molas" do processo de manipulação da memória e da história de nossa última ditadura, na medida em que é "a função seletiva da narrativa que oferece a manipulação, a oportunidade e os meios de uma estratégia engenhosa que consiste, de saída, numa estratégia do esquecimento tanto quanto da rememoração" (Ricoeur, 2007, p.98). O revisionismo e a negação, principalmente em suas dimensões mais sofisticadas, trabalham nas brechas das variações do trabalho de

9 Disponível em: http://www.bolsonaro.com.br; Acesso em: 27 jul. 2015

10 As noções de "memória manipulada" e de "esquecimento comandado" de Ricoeur são lidas por nós tendo por base os alargamentos e as reticências empreendidos em relação a tais noções por HUYSSEN, 2014, p.155-175. Ainda assim, como destacaremos, acreditamos que o caso brasileiro esteja mais próximo do espanhol do que do argentino e do alemão, que são tomados como exemplos por HUYSSEN. Destacamos ainda que, para o autor: "o esquecimento precisa ser situado num campo de termos e fenômenos como silêncio, desarticulação, evasão, apagamento, desgaste, repressão - todos os quais revelam um espectro de estratégias tão complexo quanto o da própria memória" (2014, p.158) 
configuração narrativa. "As estratégias do esquecimento enxertam-se diretamente nesse trabalho de configuração; pode-se sempre narrar de outro modo, suprimindo, deslocando as ênfases, refigurando diferentemente os protagonistas da ação assim como os contornos dela" (Ricoeur, 2007, p.455). Nesses termos, não estamos falando de apagamento de traços, mas de "astúcia" e de "má consciencia": "há também muitas aparências de apagamento que não concorrem senão para a dissimulação daquilo que permanece, pelo contrário, inapagável na experiência memorial" (Ricoeur, 2006, p.126). Sendo assim, o site Metapédia, os ofícios dos militares e o cartaz em questão fazem parte do mesmo trabalho de negação e/ou revisionismo que vimos a partir da Wikipédia? Eles ajudam a inserir o caso ocorrido na Wikipédia em um "contexto" maior?

\section{MÁQuina de RUMORES E COS - PARTE I}

Acreditamos que o trabalho de negação e/ou revisionismo é muito mais amplo do que a memória ou a perspectiva militar. Ainda assim, convém destacar que ele é fundado em uma retórica que idealiza, distorce, dissimula, justifica e milita por algum tipo de autoabsolvição. Desse modo, nossa hipótese é que os atores de tais inscrições fazem parte ou se identificam com uma complexa "comunidade de memória em rede". Em primeiro lugar, é preciso dizer que, ao contrário do que parece defender Ricoeur em A memória, a história e o esquecimento (2007), conhecer a factualidade do que ocorreu anteriormente por meio da lembrança talvez não tenha nenhum resultado terapêutico, pelo menos ligado à cura, à reconciliação ou à pacificação. Os conflitos de memória podem, ao contrário, dividir e criar mais ódios, ressentimentos e dissensos. Fazer e lutar pelo dever e trabalho de memória, bem como pelo do luto, é antes de tudo uma "intenção ética" e uma posição política, um cuidado com os mortos de ontem e com os vivos de hoje. ${ }^{11}$

A pesquisa histórica contemporânea demonstra é que a tortura e a prática dos desaparecimentos foi uma política de Estado. Assim, há uma

11 RICOEUR, 1986, p.444. Ver também RANGEL; ARAUJO, 2015. 
gigantesca desproporção assimétrica nas práticas da violência política (da resistência armada e da repressão, deixando de lado aqui o debate sobre a possível legitimidade da resistência violenta ao Estado ilegítimo, ao qual já aludimos. Além disso, os participantes da resistência armada foram punidos das mais diversas formas). No entanto, além da dimensão factual há um nível mais profundo em que deve funcionar a desconstrução da negação e do revisionismo: interpretações melhores e mais sofisticadas. No entanto, principalmente em se tratando de história do tempo presente, a tensão entre objetividade e subjetividade atinge seu ponto crítico. Considerando os limites da historiografia e suas funções sociais, políticas e éticas, é preciso reafirmar a democracia como valor fundacional da sociedade brasileira desde a Constituição de 1988, ou, na linguagem de Carlos Nelson Coutinho em texto de 1979, da "democracia como valor universal".

O reviver eticamente o passado implica refletir sobre o que se deve lembrar e o que se pode (ou se gostaria de) esquecer, pois "a memória, então, é conhecimento que vem do passado, não é necessariamente conhecimento sobre o passado" (Margalit, 2006, p.20). Assim, a "comunidade de memória" aqui analisada opera com a finalidade de falsificar e dissimilar a factualidade do que ocorreu anteriormente. No entanto, essa "comunidade" parece se "organizar" de forma mais ou menos "espontânea" em rede.

A internet e as tecnologias digitais criam e recriam outras (novas e velhas) formas de sociabilidade, ação, identidade e ativismo político. São linhas que criam elos e nós abertos, mutáveis e múltiplos de acordo com posições, disputas e emergências. Para Castells, a internet é, por excelência, a infraestrutura material das organizações e da "sociedade em rede": "la sociedad en red, la estructura social que caracteriza a la sociedad a princípios del siglo XXI, una estructura social construída al redor de (pero no determinada por) las redes digitales de comunicación" (2009, p.24). ${ }^{12}$ Assim, para o autor, uma rede pode ser definida como sendo "un

12 CASTELLS acredita que está emergindo uma estrutura social mundial constituída por redes em diversas organizações e práticas sociais, fato que possibilita a formação da "cultura da 
conjunto de nodos interconectados. Los nodos pueden tener mayor o menor relevancia para el conjunto de la red, de forma que los especialmente importantes se denominan 'centros' en algunas versiones de la teoría de redes" (Castells, 2009, p.45). Sem deixar de lado a importância da "origem" (plena ou parcial) militar da internet, cabe enfatizar que estamos falando de uma rede em que os módulos e nós mutantes e variados produzem e repercutem rumores ressignificando o "passado-presente" e, em alguma medida, o "passado irrevogável” (Jankélévitch, 1974).

Entramos aqui, portanto, em níveis de competição atravessados pela negação e/ou revisionismo em todas as suas dimensões: entre memória e memória; entre memória e historiografia; e entre memória e esquecimento. Nessa direção, não deixa de ser sintomática a publicação, em 2014, do livro Ditadura à brasileira. 1964-1985: a democracia golpeada à esquerda e à direita, de um historiador bastante presente na grande imprensa: Marco Antônio Villa. Um dos problemas desse livro é que paira sobre a argumentação de Villa a ideia da "ditabranda". Roberto Vecchi e Regina Dalcastagnè (2014, p.12) destacam que "não é inocente deixar aflorar a mitologia da dita-branda, que parece fundar uma taxonomia específica da ditadura brasileira, porque significa exumar os espectros de uma cordialidade brasileira, faca de dois gumes, mas cortante, que sempre serviu como véu da violência mais pervasiva de uma sociabilidade marcada pela permanência de dominações".

Essa "comunidade" age por meio da divisão social e institucional do trabalho de negação e/ou revisionismo em que trabalham colaboradores da Wikipédia e da Metapédia, militares ativos e da reserva, passando também, por exemplo, por boa parte da chamada "Nova Direita", por jornalistas e historiadores. (Nessa direção, o artigo de Leandro Fortes,

virtualidade real". O autor afirma que: "a passagem dos meios de comunicação de massa tradicionais para um sistema de redes horizontais de comunicação organizadas em torno da internet e da comunicação sem fio introduziu uma multiplicidade de padrões de comunicação na base de uma transformação cultural fundamental à medida que a virtualidade se torna uma dimensão essencial da nossa realidade" (2011, p.I-II); "a internet, a World Wide Web e a comunicação sem fio não são mídias no sentido tradicional. São, antes, os meios para a comunicação interativa" (2011, p.XI). 
“Saudades de 1964", publicado na revista Carta Capital em 7/12/2012, lido hoje, não deixa de ter um tom antecipatório do que viria a ocorrer depois). Esses atores ocupam discursos, posições e funções mutáveis no interior da rede. Não sem razão, no presente, mesclam-se, associam-se e são, também, porta-vozes de certos fundamentalismos crescentes em diversos domínios do Brasil atual, especialmente dos fundamentalismos que re-agem à presença de um governo de "esquerda" desde 2003.

Nessa direção, "ser fundamentalista de certa tradição significa acreditar que as lembranças dos eventos que pertencem àquela tradição são efetivamente lembranças dos eventos passados" (Margalit, 2006, p.6), pois, para o tradicionalista, a memória em si tem mais importância que a sua verdade, mesmo que ela negue e/ou revise, isto é, que não aceite e distorça a factualidade do que ocorreu anteriormente ou, simplesmente, que construa interpretações fundamentalistas que servem mais aos combates do presente do que a compreensão e explicação da experiência histórica. Não sem razão, Jankélévitich (1974), em sua distinção entre o irreversível (o fato, por exemplo, de não podermos voltar ao passado e nem de fazer o passado retornar) e o irrevogável (o "ter sido" não pode ser destruído, o que foi feito não pode ser desfeito, é inapagável), afirma que o sentimento nostálgico está bem próximo do “irrevogável”, já que é o pesar do nunca mais, do reviver. Já o remorso gostaria de apagar, de não ter vivido. Assim, o remorso carrega uma dimensão ética, ao passo que a nostalgia dimensões estéticas e práticas (Ricoeur, 2007, p.493).

Assim, trata-se, para os diversos membros da "comunidade de memória em rede" aqui analisada, da capacidade de transmitir e de difundir uma versão do que se passou "santificada, autorizada, ou ainda canonizada em modo tal de ser imune ao confronto baseado em um percurso historiográfico alternativo" (Margalit, 2006, p.56). Ela distorce e justifica o que se passou também por idealizá-lo. ${ }^{13}$ Essa "comunidade de memória" não deseja reconhecer os crimes do passado-presente, pois deve manter uma relação de fidelidade com seus antepassados: "uma comunidade de

13 Ver o vídeo Regime Militar Democrático. Disponível em: https://www.youtube.com/watch?$\mathrm{v}=\mathrm{vcKBnZYRuNI}$; Acesso em: 14 ago. 2015. 
memória não é baseada só em relações frequentes que ocorrem agora entre os vivos, mas também com sua relação com os mortos" (Margalit, 2006, p.62). É um tipo de fidelidade que funciona, no interior da "comunidade de memória" aqui analisada, para justificar, autojustificar e também se autoabsolver dos erros e crimes imputados à comunidade. Na medida em que não houve punição, essa comunidade se percebe com grande autonomia narrativa em relação à comunidade maior, no caso, a Nação.

Essa narrativa justifica no presente, em particular, práticas, discursos, ideologias e lógicas que permanecem. Em grande medida, a impunidade em relação aos crimes praticados pelo Estado durante o período de 1964-1985 é o principal motor que faz com que essa "comunidade de memória” persista, cresça e se transforme e, sobretudo, que não sinta ou manifeste remorso ou culpa e, por consequência, não aceite nem reconheça qualquer tipo de erro. Em vez do remorso ou da culpa assistimos ao estímulo ao ódio e ao ressentimento. Afetos que também impedem ou dificultam um pedido de desculpas e/ou perdão pelos erros praticados: "o próprio das afecções é sobreviver, persistir, permanecer, durar, conservando a marca da ausência e da distância (...); nesse sentido, essas inscrições-afecções conteriam o segredo do enigma do rastro mnemônico". Ainda sim, é preciso destacar, "cabe à noção de inscrição comportar referência ao outro; o outro que não a afecção enquanto tal. A ausência, como o outro da presença!" (Ricoeur, 2007, p.436, p.36).

Sendo assim, a "guerra de memória", diante de seus sentimentos e de seus componentes de irracionalidade, não terminará apenas pelo uso da razão, da lembrança e da evidência, mas antes de tudo quando os atos e os agentes de crimes realizados no passado sofrerem algum tipo de punição. Afinal, "na dimensão social só se pode perdoar onde se pode punir" (Ricoeur, 2007, p.608, grifo nosso). Não há, portanto, para Ricoeur, uma incompatibilidade entre "reconciliação" e punição. ${ }^{14}$ No

14 Destacamos que a presença e os trabalhos da Comissão Nacional da Verdade podem ter incentivado também a "vingança" e/ou "queima de arquivo". Ver, por exemplo: http://noticias. uol.com.br/ultimas-noticias/agencia-estado/2014/04/25/coronel-que-confessou-tortura-e -encontrado-morto.htm; Acesso em: 02 jul. 2015. 
entanto, suas posições devem ser utilizadas com prudência para pensar o caso brasileiro. De algum modo, as perspectivas de Margalit e Huyssen nos ajudam a complexificar nossas especificidades.

É preciso pensar também na definição de crimes ou pelo menos em algum tipo de responsabilização para a maneira como tem se dado a expressão pública do "novo sentimento antidemocrático" (Rancière, 2014)? É possível responsabilizar indivíduos que expõem faixas que clamam (pelas mais diversas razões, sejam elas fantasiosas, reais, metafóricas ou até mesmo irônicas) pelo "retorno da Ditadura" ou "dos militares"? "A coisa tem por que suscitar medo e, portanto, ódio, entre os que não estão acostumados a exercer o magistério do pensamento. Mas, entre os que sabem partilhar com qualquer um o poder igual da inteligência, pode suscitar, ao contrário, coragem e, portanto, felicidade" (Rancière, 2014, p.122). A guerra de memória, quando se divide entre um combate entre "esquerdistas" e "direitistas", aceita diversos pressupostos da lógica autoritária. No entanto, a democracia não pode ser "conquistada" por nenhuma ideologia: a democracia pressupõe a intensificação da pluralidade, do justo, da simetria e do dissenso.

\section{INTERMEZZO}

Do "clima" de otimismo ao medo? Do medo ao ódio? Do neodesenvolvimentismo ao ajuste fiscal? Do "Gigante Adormecido" da propaganda da empresa Johnnie Walker ao 7 a 1 da Alemanha sobre o Brasil?

Roland Barthes, no texto "O rumor da língua", afirma que "o balbucio (do motor ou do sujeito) é, em suma, um medo". Os rumores aqui evocados têm medo de quê? Ao que parece, no mínimo, nos impedem de "ouvir", ver e identificar a estrutura das lógicas, das práticas, das ações e dos pensamentos de matizes autoritários de uma parcela significativa da sociedade brasileira. Estrutura essa que sustenta, naturaliza, legitima e (re)produz a desigualdade e a sua invisibilidade, bem como os silenciamentos e as indiferenças em relação àquilo que nos constitui (seria “apenas" o que resta da escravidão?). E é inegável que nos últimos anos houve uma maior democratização - ou pelo menos iniciativas de 
democratização - de espaços antes apenas ocupados pelas elites e classes médias altas. A “comunidade de memória” aqui estudada é, assim, produto e produtora de uma visão da sociedade e da história brasileira que defende e reproduz a dimensão hierárquica, violenta e desigual da nossa história. A negação, em geral, pretende inibir alguma coisa (Virno, 2013, p.167). No nosso caso, qualquer tipo de transformação da sociedade em dimensões mais justas e democráticas: "uma democracia que tolera desigualdades pode cumprir os requisitos da legalidade, mas jamais será uma ordem legítima” (Nobre, 2013, p.126).

A negação e certos revisionismos produzem a sobra, a não inscrição. Assim, seu sentido estrutural é impedir algum tipo de produção de visibilidade. Toda e qualquer possibilidade de criação de visibilidade é combatida, mormente daqueles que não eram ou não são vistos, que foram ou são cotidianamente apagados, ontem e hoje. Nessa direção, a guerra de posições dessa "comunidade de memória em rede" aqui retratada pode ser interpretada como uma re-ação à possibilidade de fixação, de fundação de uma memória pública, compartilhada e aceita daquela experiência?

Quais as "bases sociais" dessa "comunidade de memória"? Essa talvez seja uma das questões mais difíceis de enfrentar. Em 1987, Antônio Flávio Pierucci, em seu texto "As bases da nova direita", afirmava que "seu tique mais evidente é sentirem-se ameaçados pelos outros": "eles têm medo"! Segundo o autor, "a nova direita prima portanto por diagnosticar a crise geral do presente como uma crise primeiramente cultural, uma crise de valores e de maneiras. Crise moral”. Pierucci procura identificar o outro da "Nova Direita": "e não seriam, porventura, os chamados 'novos' movimentos sociais exatamente o Outro da 'nova' direita, o inimigo principal em relação ao qual ela se recorta, e contra o qual já se pôs em movimento?". ${ }^{15}$

Além disso, apesar de sua pluralidade e diversidade, seus membros, militantes e simpatizantes temiam dizer seu nome. Seria a sombra da Ditadura? Passados mais de vinte e cinco anos, é a esquerda que teme

15 PIERUCCI, 1987, p.26, p.45. Ver também COWAN, 2014. 
dizer seu nome? (Saflatle, 2012). A dificuldade em se conceituar o "novo" é que ele pode vir "travestido" de "velho", ou ainda, da repetição: "apenas se reconhecermos aquilo que pode se repetir a qualquer momento - mesmo que nem sempre ao mesmo tempo - seremos capazes de mensurar aquilo que é realmente novo em nosso tempo. Talvez seja menos do que imaginemos. Mas esse ponto é decisivo". Nessa perspectiva, o passado-presente se transforma em presente-passado. Afinal, "certas dimensões de natureza diacrônica e sincrônica são escalonadas em profundidade temporal variada" (Koselleck, 2014, p.246, p.245). Esse jogo possibilita que a memória crie suas eclusas. Há, no mínimo, três fatores "novos" durante o "nosso recorte": a difusão da internet; a presença no poder de um partido (do ponto de vista simbólico convém destacar: liderados por um ex-metalurgico e sindicalista; e por uma mulher presa e torturada pela Ditadura) com certas políticas (reais e imaginárias) de "esquerda" por quase dez anos no poder; e a presença de uma Comissão Nacional da Verdade.

Não é casual, assim, que o Golpe e a Ditadura sejam mobilizados em nossos "dramas sociais" no início da segunda década do século XXI; também não é por acaso que nossa Comissão da Verdade só tenha se constituído, sem poder punitivo, depois de quase trinta anos do fim da Ditadura. Nessa direção, Abreu afirma que "no contexto crítico dos anos 1960, figurava-se a história política da década de 1930 como resposta adequada aos dramas do presente. Um drama desdobrava-se em outro, requerendo interpretações que ultrapassassem os limites da memória histórica" (2012, p.25). As disputas em torno da questão da desigualdade, que transforma cerca de $30 \%$ da população em excluídos sociais é, assim, a base dos atuais conflitos sociais no Brasil (Souza, 2014). As recentes (e frágeis) conquistas das classes populares em termos de educação e saúde estão, certamente, no centro do debate, ainda que intimamente atreladas a "blindagens" e "pactos" que "fundaram" e permaneceram durante a "nova república" (Pochmann, 2015; Nobre, 2013).

Alguns estudos sugerem que, em comparação com jovens argentinos e uruguaios, os brasileiros são os que menos têm interesse no passado militar e os que têm menores rejeições a "opções militaristas" (Duarte; 
Cerri, 2012.). Mais ou menos nessa linha, Adriano Cerqueira e Rodrigo Patto Sá Motta (2015), analisando os dados de uma pesquisa realizada em 2010 em alguns estados sobre o Golpe de 1964 e a Ditadura Militar, afirmam que há um "elevado índice de pessoas que não souberam responder às questões, demonstrando total desconhecimento (ou esquecimento) dos eventos e processos relacionados ao golpe de 1964 e ao regime militar dele decorrente". ${ }^{16}$

Além disso, cabe ainda destacar que é preciso investigar melhor as conexões, o embaralhamento e as hibridações entre a chamada "nova" (não tão nova assim) e a "velha" direita. Há alguns discursos que nos levam a crer que alguns de seus membros (anacronicamente?) ainda vivem no tempo da Guerra Fria, do anticomunismo; e outros mais conectados ao "tempo presente", mas que, muitas vezes, fundamentam seus discursos em questões morais, ou "simplesmente" "abusam" na interpretação dos fatos para o combate político imediato. Também seria necessário pensar nas relações entre a "nova" e a "velha" esquerda, bem como nos sentidos e na atualidade dos projetos e relações entre esquerda, centro e direita no Brasil contemporâneo. Nessa perspectiva, para concluir esse intermezzo, é preciso sublinhar, junto a Andreas Huyssen, que “o esquecimento efetivamente cria a memória” (2014, p.157).

\section{MÁQUINA DE RUMORES - PARTE II}

Para Márcio Seligmann-Silva, a difícil e precária inscrição dos eventos violentos ocorridos durante a ditadura brasileira em nossa "memória cultural" está relacionada com uma "ausência de ressonância" na esfera pública. De algum modo, como já adiantamos, a "negação e/ou revisionismo brasileiro" também não podem ser vistos como uma re-ação a uma frágil inscrição pública? Em outras palavras, não estaríamos saindo de um regime da não inscrição pública para um início fragmentário de

16 Agradeço a Adriano Cerqueira e a Rodrigo Patto Sá Mota a gentileza de disponibilizar a pesquisa. 
elaboração e fixação, isto é, de inscrição precária, tênue ou frágil? Ou ainda, como os rumores são produtos e produtores de ressonâncias?

Do nosso ponto de vista, a negação e/ou revisionismo aqui destacado são impedimentos à construção de uma "justa memória”, isto é, de uma memória "salva" dos abusos da memória, da história e do esquecimento (Ricoeur, 2007); ou, se quisermos deixar de lado a utopia da "justa memória", de uma "memória partilhada" da Ditadura Militar brasileira, isto é, de uma "memória pública" que aceite interpretações diversas (Margalit, 2006). Acreditamos que os conflitos de memória, para terem certa memória compartilhada, necessitam da intervenção de um terceiro, a fim de que o dissenso seja parte do conviver com a pluralidade. Cabe sempre destacar que as disputas de memória são também disputas de poder, em especial os conflitos em torno de um "passado" que ainda é atual, como é o caso da Ditadura Militar brasileira.

Os conflitos de memória e o combate à negação e a certos revisionismos têm auxiliado a revelar ou a descobrir as marcas, as cicatrizes do passado -presente, criando uma atmosfera em que se torna possível inscrever de forma sutil essas marcas na memória pública de toda a nação e não só na de grupos particulares. No entanto, a pedra no caminho é bem sublinhada por Jeanne Marie Gagnebin (2013), que afirma, dentre outras coisas, que há, no Brasil, uma ideologia que sustenta que, por um lado, não é necessário lembrar, pois nada muda verdadeiramente, e, por outro, que é necessário olhar para frente. Ao que parece, a ideia de que "águas passadas não movem moinho" constitui uma parte substantiva de nossa cultura, ou, pelo menos, de grande parte de nossas elites ou, no mínimo, dos matizes do autoritarismo passado-presente e presente -passado. Talvez essa dimensão cultural e ideológica quase sempre nos imponha uma "conciliação por inércia" diante da dimensão cruenta da história do Brasil, o que nos leva a arremessar para um futuro abstrato os grandes problemas (Rodrigues, 1965). Como esclarece André Freixo (2012), o problema para José Honório Rodrigues não é a conciliação em si mesma, mas a tradição de "conciliação pelo alto". 
Roberto Vecchi (2014), apoiado em José Gil (2007), aproxima a memória da guerra colonial portuguesa e a do autoritarismo brasileiro destacando que ambos os países são, de algum modo, países da "não inscrição", constantemente assombrados por aquilo que não se inscreveu e pelo luto que não teve fim. No caso do Brasil, o autor acredita que ainda se está diante de eventos em busca de um nome, "onde a incapacidade de nomeá-los corresponde, num plano simbólico, a uma incapacidade de pensá-los como fundadores de uma memória compartilhada ainda que traumática”. Uma alternativa a essa instabilidade, para o autor, é a projeção política da memória e da verdade no espaço público, muito além de recordações de grupos ou indivíduos.

A não inscrição é assim um lugar onde a escrita, a imagem e palavra não se inscrevem, um branco psíquico, uma incapacidade de registrar e elaborar os acontecimentos que marcam uma história (Gil, 2007; Albuquerque Júnior, 2012). A não inscrição é, portanto, do nosso ponto de vista, uma negação e/ou um revisionismo específico - ou, no mínimo, uma tentativa de - que pretende apagar e/ou distorcer as "marcas do passado". Nessa direção, com base em Gil e Barthes, qual é o medo que os rumores aqui evocados revelam?

Esse medo, que encobre certas estruturas do autoritarismo presente e persistente em diversas camadas sociais no Brasil, em muitos casos está estreitamente relacionado com diversos tipos de ressentimento do presente e do passado-presente, em especial após a presença, desde 2003, de governos que se percebiam (e se percebem) e que também eram (e são) considerados por muitos atores políticos como sendo de "esquerda”. Há, assim, dimensões estruturais e que permanecem em boa parte do discurso da chamada "nova direita". Nesse sentido, uma de nossas conclusões é que é preciso compreender melhor a relação entre negação, revisionismo, medo e ressentimento. Além disso, há dimensões que ultrapassam a competição ideológica, partidária e conjuntural, há dimensões e estratos estruturais e repetitivos que precisam ser escavados e pensados. Além da presença da Comissão da Verdade no período aqui analisado, desde a década de 1970 (ou mesmo já na década de 1960) 
diversos atores contribuíram e têm contribuído para a germinação e desenvolvimento dessa inscrição frágil. ${ }^{17}$

Destacaremos aqui brevemente o papel da historiografia e da pesquisa acadêmica em geral. A maioria das análises sobre a Ditadura Militar parte, em geral, da denúncia da ausência de punição para três fatos: as práticas sistemáticas de tortura, a execução de prisioneiros e a "morte da morte": ocultação/eliminação de cadáveres (Oliveira, 2011; Martins Filho, 2003; Gagnebin, 2013; Safatle; Teles, 2010). Assim, é preciso problematizar a suposta "vitória simbólica dos vencidos" nas "guerras de memória" (Teixeira, 2012; Rollemberg, 2006), bem como alguns persistentes silêncios (Reis, 2010).

Apesar disso, é preciso considerar também que nos últimos dez anos o silêncio vem sendo quebrado e tem havido certo reconhecimento de direitos de vítimas e de famílias das vítimas. De "incômoda" (Reis, 2000) à memória da Ditadura tem se tornado, ao que parece, objeto de disputa, de conflito, de interpretação, de revisão. Em grande medida, tais mutações se devem, portanto, às quebras (parciais e frágeis) dos silêncios e silenciamentos que encobriam e sustentavam tal "incômodo". Porém, a vigência da Lei da Anistia de 1979 é apontada pela maioria dos estudiosos como um dos maiores obstáculos à construção de uma "memória compartilhada" sobre aquele passado-presente, além de legitimar a impunidade (Schneider, 2011; Fernandes, 2013; Silva, 2009; Pereira, 2010).

Nessa direção, Benito Schmidt afirma que as "batalhas de memória" em relação à Ditadura Militar mobilizam, no mínimo, três "discursos de

17 É possível que o desenvolvimento dessa inscrição frágil se relacione com a intensificação da oscilação de duas funções que nos constituiriam: "creio que a cultura brasileira, na sua tentativa de escrever a sua própria história, tenha seguido contemporaneamente e de modo labiríntico esses dois caminhos: ou seja, que ela tenha, por um lado, negado o passado, sacralizando-o em uma espécie de recalque simbólico, sem todavia, esquecer, por outro, que esse espaço oco pode ser um 'tempo em palimpsesto' em que pulula o eventual, que, melhor, o lugar do morto pode vir a ser a dimensão dos vivos, o lugar narrativo em que o presente se localiza, no 'fazer memória' daquilo que 'já foi”' (FINAZZI-AGRÓ, 2013, p.33). 
memória" (que podem ser diversos em seu interior): o governamental; o dos militares; e o dos militantes de esquerda, das vítimas de tortura e dos familiares dos mortos e desaparecidos políticos. Poderíamos acrescentar um quarto e um quinto tipo: o discurso do especialista; e também o da mídia, que articula os discursos anteriores via espetacularização, contribuindo tanto para o trabalho de luto quanto para a banalização. Mesmo sem considerar como um "discurso de memória", para Schmidt, a mídia tem sido fundamental em um trabalho de "enquadramento da memória" em que a tortura é vista como parte de uma "guerra suja" e não como uma prática política do Estado: "[a Ditadura Militar] teria sido completamente alheia ao 'povo brasileiro', portador de profundas convicções democráticas, e, no final, acabaria vencida por ele" (2006, p.92).

Nesse sentido, pode-se considerar o Brasil uma exceção em relação aos seus vizinhos latino-americanos onde, por exemplo, as vítimas e seus representantes assumiram um amplo protagonismo memorial público (Sarlo, 2007). Gagnebin considera que "o Brasil não faz parte desse Sul da América Latina” (2013, p.150). Na mesma direção, Carlos Fico destaca que, "diferentemente da Argentina (para mencionarmos um exemplo próximo), o traço marcante da memória sobre a Ditadura Militar brasileira não é o trauma pela violência, mas a frustração das esperanças" (2012, p.50). Não se pode, no entanto, dizer que a nossa justiça transicional incompleta seja responsável pelos males de nossa democracia. Se assim fosse, teríamos que dizer que Argentina e Portugal vivenciam uma "qualidade" democrática superior à nossa. Porém, não sem razão, é no Brasil e na Espanha, que vivenciaram transições próximas, que as "comunidades de memória" aqui analisadas ganham mais visibilidade e adeptos.

A negação e o revisionismo foram eleitos por nós como elemento importante para a compreensão dessa guerra de memória, pois cremos que eles têm um papel importante no impedimento ou na edificação de uma "justa memória", pois dificultam o arrependimento, a culpa e o remorso por parte dos apoiadores, encobridores e perpetradores de crimes imprescritíveis e ações imorais, como a prática da tortura e assassinatos ontem $e$ hoje, ontem $e$ amanhã. Acreditamos que a ampliação desse 
tipo de lógica pode ser relacionada, pelo menos no plano simbólico, a algum tipo de re-ação a uma possível "inscrição frágil” de uma memória pública daquele passado-presente que, em certa medida, pode ter sido intensificado pela existência e pelos trabalhos da Comissão da Verdade (ainda que se possam fazer muitas críticas justas a esta). Essa re-ação cria, ao mesmo tempo, mais força para a luta pela verdade e pela justiça e, assim, as condições para a edificação dessa frágil inscrição.

Por outro lado, paradoxalmente, a capilaridade e a aceitação da negação e/ou do revisionismo alimentam ainda mais a ausência de arrependimento, remorso ou mesmo culpa por parte dos perpetradores e de seus apoiadores. No entanto, tal dimensão não é necessária e fundamental para que algum tipo de punição e/ou elaboração ocorra. A esse respeito é preciso dizer que há elementos de continuidade entre alguns "militantes ativos" na negação e/ou revisionismo. Há atores direta ou indiretamente ligados à ditadura, e, em geral, há presença de pessoas que foram ligadas à estrutura repressiva (Teixeira, 2012).

Além da punição, é preciso também um pedido de perdão ou desculpas não apenas do Estado como entidade abstrata, como vem ocorrendo de vários modos desde 1994. O pedido de desculpas deve ocorrer também por parte das Forças Armadas, além do reconhecimento de sua responsabilidade em relação aos crimes cometidos durante a ditadura, tal como sugerido pelo relatório final da Comissão da Verdade. Mas, levando-se em consideração o atual estágio do conflito, alimentado ainda mais pelo contexto pré e pós-eleição presidencial de 2014, tal posição pode estar cada vez mais distante, pois, ao que parece, não há consciência afetiva do erro ou, no mínimo, um arrependimento público. Não há também "clima político" para a revisão e/ou anulação da Lei da Anistia no Congresso ou no Supremo Tribunal Federal. Ainda sim, convém destacar que, em março de 2014, em pesquisa do Datafolha, cresciam os entrevistados a favor da anulação da Lei de Anistia: 46\% favoráveis e 37\% contrários. Porém, "os resultados mostram uma sociedade dividida". 18

18 Disponível em: http://www1.folha.uol.com.br/poder/2014/03/1433374-maior-parte-da-populacao-quer-anular-lei-da-anistia-aponta-datafolha.shtml; Acesso em: 06 jul. 2015. Ver 
Chama a atenção também o fato de $80 \%$ dos entrevistados defenderem que tanto ex-militantes quanto torturadores deveriam ser julgados hoje.

A intervenção de um terceiro, no caso, de uma Comissão da Verdade sem poder punitivo, abriu a possibilidade do debate e criou algum tipo de distância entre as vítimas e os agressores. Para Ricoeur (1995), o reconhecimento público da vítima como ser humilhado e ofendido possibilita, por parte desta, a restauração da estima de si e contribui para o trabalho de luto. Esse reconhecimento pode, ainda, educar a opinião pública para os valores da equidade. Em certo sentido, a Comissão, em seu relatório final, "repara" a indistinção entre o algoz e a vítima presente na ideia de crimes conexos na Lei da Anistia. No relatório final, essa indistinção se transforma em uma distinção, na medida em que há a definição dos crimes e dos criminosos. Os responsáveis por violações de direitos humanos são nomeados, e na lista figuram ex-presidentes da República e chefes militares. Não podemos menosprezar, pelo menos no plano simbólico, os efeitos dessa distinção. Além disso, tendo em vista nossa análise, consideramos relevante a recomendação de que as Forças Armadas reconheçam sua responsabilidade em relação aos crimes cometidos durante a ditadura. Do nosso ponto de vista, portanto, o relatório cria possibilidades para que a inscrição possa deixar a fragilidade de lado. Otimismo? Talvez. De todo modo, é preciso destacar que é provável que Andreas Huyssen tenha muita razão quando afirma que tentar legislar sobre o esquecimento "é tão inútil quanto tentar legislar sobre as maneiras corretas de lembrar" (2014, p.160).

A memória suscita vingança tão frequentemente quanto suscita reconciliação, e a esperança de alcançar uma catarse através da liberação da lembrança pode revelar-se uma ilusão (Margalit, 2006, p.14).

também: http://www.cartacapital.com.br/sociedade/lei-de-anistia-nao-e-obstaculo-parajulgar-torturadores-8107.html; Acesso: 04 ago. 2015. 
No limite, diversos conflitos, posições e argumentos aqui citados e analisados estão mais ligados a confrontos de interpretação e a estratégias do esquecimento (por meio das brechas constitutivas das variações do trabalho de configuração narrativa) do que relacionados apenas a uma deturpação e negação da factualidade (a crítica nesse "nível" é um procedimento necessário, mas insuficiente para a desconstrução e confrontação da negação, do negacionismo e do revisionismo). Para Ricoeur, a história tem o privilégio "de corrigir, criticar e até mesmo desmentir a memória de uma comunidade determinada". O autor ainda afirma que "é no caminho da crítica histórica que a memória encontra o sentido de justiça" (Ricoeur, 2007, p.507). Segundo nossa pesquisa, essa última afirmação encontra sérios problemas se pensada para o nosso caso. Pelo menos no Brasil, a crítica histórica apresenta muitas dificuldades em ter o privilégio da condução dos debates públicos. Em sua função mediadora, talvez possa contribuir modestamente ao oferecer opções éticas melhores e mais justas a partir da sua função crítica. Por outro lado, nossa investigação nos dá elementos para afirmar que a presença de um "passado irrevogável" não é uma condição exclusiva das vítimas diretas e indiretas de alguma forma de violência. Seria interessante, assim, estender e complexificar a compreensão que Berber Bevernage tem em sua contraposição entre o "discurso da vítima" e o "discurso da historiografia" (2011).

Reiteramos que a negação, e em especial o revisionismo, é um tipo radical e perigoso de fundamentalismo (diverso, portanto, do relativismo cultural, que é inclusivo e reconhece o valor da diversidade), pois coloca em questão o poder de veto das fontes com base em lógicas de justificação e dissimulação que pretendem extrapolar, estender, manipular, e, no limite, negar o poder de veto das fontes. ${ }^{19}$ Em outros termos, nega

19 Nas palavras de Koselleck: "A ciência histórica atual se encontra, portanto, sob duas exigências mutuamente excludentes: fazer afirmações verdadeiras e, apesar disso admitir e considerar a relatividade delas. [...]. Uma fonte não pode nos dizer nada daquilo que cabe a nós dizer. No entanto, ela nos impede de fazer afirmações que não poderíamos fazer. As fontes têm poder de veto. [...]. As fontes nos impedem de cometer erros, mas não nos revelam o que devemos dizer. Aquilo que faz da história história não poderá jamais ser deduzido a partir das fontes. Para que estas finalmente falem, faz-se necessária uma teoria da história possível” (KOSELLECK, 2006, p.161, p.188, grifo nosso). 
e/ou revê a dimensão política e a intenção ética que valoriza e estimula o dissenso, a pluralidade e o diálogo que fundamenta a experiência democrática. A interação entre a ética e a política pressupõe a exigência de um reconhecimento mútuo. A ética do político, nessa perspectiva, visa a criar espaços de liberdade. Essa intenção ética na esfera do político não depende apenas dos sujeitos, mas também do Estado de direito (Ricoeur, 1986, p.444). Além da refutação e da desconstrução factual é preciso criar espaço de diálogo, de liberdade e de pluralidade para estabelecermos os limites das narrações, interpretações e representações. Nessa direção, destacamos que o relatório final da Comissão da Verdade deve ser louvado, pois criou a possibilidade ética e política de justiça ao estabelecer uma distância entre a vítima e o agressor, fundamentalmente ao definir os crimes e nomear os criminosos.

Em tempos de crescente desterritorialização da memória, as guerras de memória, como invocação à lembrança, contribuem para um importante trabalho público, apesar de a internet criar maiores possibilidades de desenvolvimento e expressão da negação e/ou revisionismo. Assim, em grande medida, por exemplo, a maioria dos colaboradores da Wikipédia tem se portado como guerrilheiros da "factualidade do passado", mesmo que prisioneiros de uma concepção de verdade que poderíamos chamar de "realismo ingênuo".

Nessa direção, apontamos que há indícios de que pode estar acontecendo, no Brasil contemporâneo, uma transformação da lógica da "não inscrição" (Gil, 2007) para a da "inscrição tênue" (Seligmann-Silva, 2014), isto é, da inscrição em fase inicial de elaboração, ainda que atravessada ou, até mesmo, paradoxalmente alimentada pela negação e/ou revisionismo. Mesmo que não haja uma relação direta, é provável que sejam, dentre vários outros fatores sincrônicos e diacrônicos, efeitos positivos da presença da Comissão Nacional da Verdade durante os anos 20122014. É possível pensar que as duas imagens abaixo expressam bem a fragilidade e a força do que se está chamando de "inscrição tênue" desse tempo que ainda é atual: 


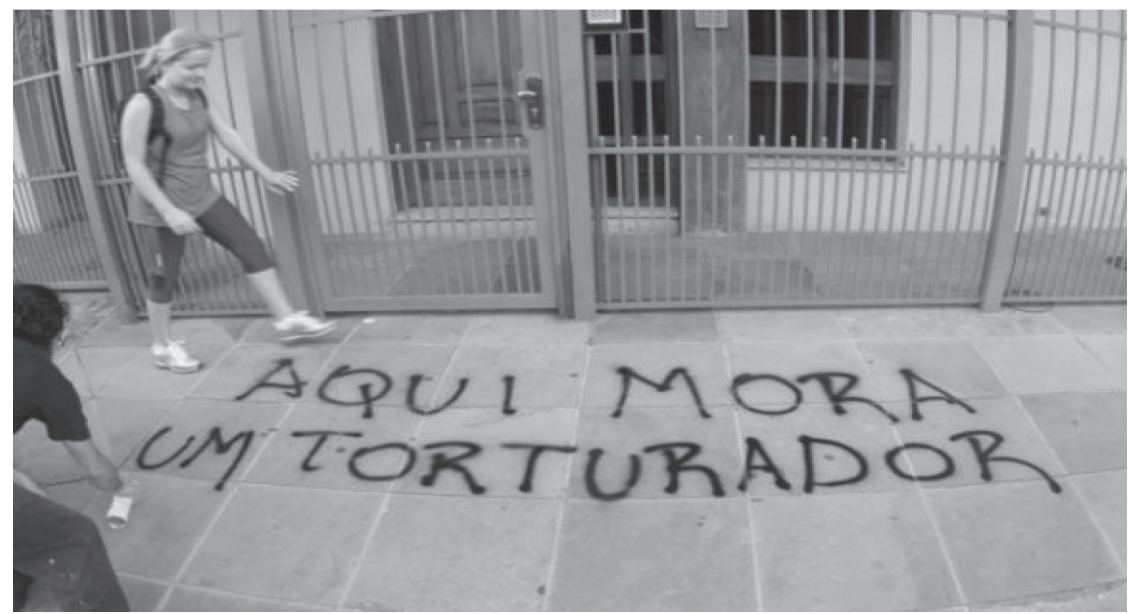

Imagem 2: "Aqui mora um torturador", 26 mar. 2012. Disponível em: http://www.conversaafiada.com.br/brasil/2012/03/26/jovens-fazem-atos-contra-torturadores; Acesso em: 07 set. 2013.

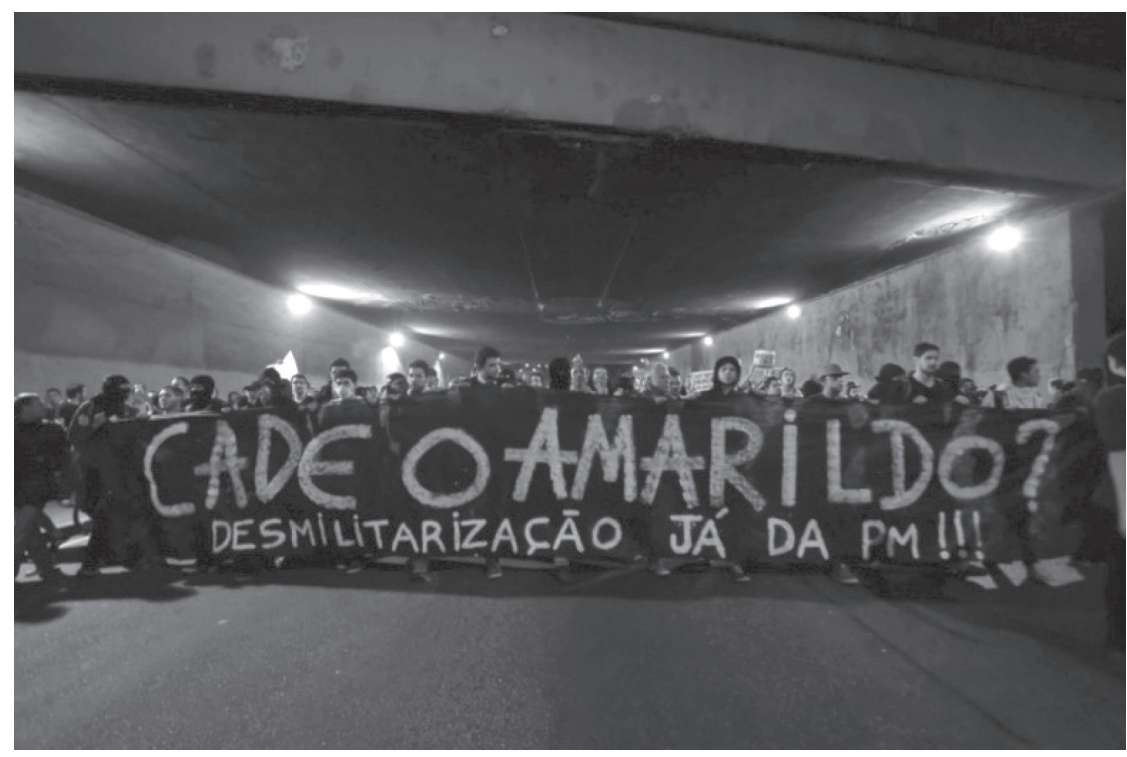

Imagem 3: “Cadê o Amarildo?", ago. 2013. Disponível em: http://www.rededemocratica.org/images/2013/08/protesto-amarildo-desmilitarizacao-pm.jpeg; Acesso em: 07 set. 2013. 


\section{Agradecimentos}

Agradeço a paciência, a interlocução e o estímulo de André Voigt, Alexandre Avelar, André Freixo, Anita Lucchesi, Breno Mendes, Carolina Figueira, Frederico Fernandes, Roberto Vecchi, Luca Bacchini, Valdei de Araujo, Sérgio da Mata, Francisco Gouvea, Fernando Nicolazzi, Frederico Fernandes, Anselmo Pessoa, Francisco Frutos, Marcelo Abreu, Luisa Rauter, Miriam Hermeto, Mauro Teixeira e Henrique Estrada. Tive também o apoio da Ufop, da Fapemig, do CNPq e da Capes, sendo que a reflexão contou ainda com o suporte do projeto "Variedades do discurso histórico" (Pronem/Fapemig-Nehm/Ufop). Tenho ainda a agradecer as sugestões dos pareceristas anônimos da revista Varia História.

\section{REFERÊNCIAS BIBLIOGRÁFICAS}

ABREU, Marcelo. Drama social e história. In: AVELAR, Alexandre de Sá et al (org.). Contribuições à história intelectual do Brasil Republicano. Ouro Preto: EDUFOP/PPGHIS, 2012.

ALBUQUERQUE JÚNIOR, Durval Muniz de. As Sombras Brancas. In: VARELLA, Flávia et al (org.). Tempo Presente \& Usos do Passado. Rio de Janeiro: FGV, 2012.

ARAUJO, Valdei Lopes de. História da historiografia como analítica da historicidade. História da Historiografia, n. 12, p.34-44, 2013.

BEVERNAGE, Berber. History, memory and state-sponsored violence. New York/London: Routledge, 2011.

BLANCHARD, Pascal; VEYRAT-MASSON, Isabelle. Les guerres de memoires. In: BLANCHARD, Pascal; VEYRAT-MASSON, Isabelle (org.). Les guerres de mémoires - La France et son Histoire. Paris: La Découverte, 2008. p.15-49.

BOBBIO, Norberto; MATEUCCI, Nicola; PASQUINO, Gianfranco. Dicionário de Política, vol. 1. Brasília: Universidade de Brasília, 2004.

CASTELLS, Manuel. A sociedade em rede. São Paulo: Paz e Terra, 2011.

CASTELLS, Manuel. Comunicación y poder. Madrid: Alianza Editorial, 2009. 
CERQUEIRA, Adriano; MOTTA, Rodrigo Patto Sá. Memória histórica. [Pesquisas de opinião sobre o golpe de 1964 e a Ditadura]. (Mimeo), 2015.

COWAN, Benjamin Arthur. "Nosso Terreno" crise moral, política evangélica e a formação da 'Nova Direita' brasileira. Varia Historia, vol. 30, n. 52, p.101-125, 2014.

D'ANDRÉA, Carlos Frederico de Brito. Processos editoriais auto-organizados na Wikipédia em português. Tese (Doutorado em Linguística) - Universidade Federal de Minas Gerais. Belo Horizonte, 2011.

DUARTE, Geni Rosa; CERRI, Luis Fernando. Politização e consciência histórica em jovens brasileiros, argentinos e uruguaios. Diálogos, vol. 16, p.229-256, 2012.

FERNANDES, Juliana Ventura. Os limites do consenso. Dissertação (Mestrado em História) - Universidade Federal de Minas Gerais. Belo Horizonte, 2013.

FERRO, Marc. Regard sur les guerres de mémoires dans le monde. Hermès, n. 52, p.9-12, 2008.

FICO, Carlos. História do Tempo Presente, eventos traumáticos e documentos sensíveis: o caso brasileiro. Varia Historia, vol. 28, n. 47, p.43-59, 2012.

FICO, Carlos. O grande irmão. Rio de Janeiro: Civilização Brasileira, 2008. FINAZZI-AGRÒ, Ettore. Entretempos. São Paulo: Unesp, 2013.

FREIXO, André de Lemos. A arquitetura do novo. Tese (Doutorado em História) - Universidade Federal do Rio de Janeiro. Rio de Janeiro, 2012. FREUD, Sigmund. A negação. Obras completas, vol. 16. São Paulo: Cia das Letras, 2012 [1925].

GAGNEBIN, Jeanne Marie. Enterrer les morts. In: DOSSE, François; GOLDENSTEIN, Catherine (org.). Paul Ricoeur: penser la mémoire. Paris: Seuil, 2013. p.149-164.

GIL, José. Portugal, hoje - O medo de existir. Lisboa: Relógio d'água, 2007. HUYSSSEN, Andreas. Culturas do passado-presente. Rio de Janeiro: Contraponto, 2014.

JANKÉLÉVICH, Vladimir. L'Irréversible et la Nostalgie. Paris: Flamarion, 1974.

JASPERS, Karl. La culpabilité allemande. Paris: Les Editions de Minuit, 1990 [1946]. 
JOHNSON, Telma. Nos bastidores da Wikipédia lusófona. Tese (Doutorado em Comunicação Social) - Universidade Federal de Minas Gerais. Belo Horizonte, 2009.

KOSELLECK, Reinhart. Estratos de tempo. Rio de Janeiro: Contra-ponto; Puc-Rio, 2014.

KOSELLECK, Reinhart. Futuro passado. Rio de Janeiro: Contra-ponto; Puc-Rio, 2006.

MARANHAO, Bernando Costa Couto de Albuquerque; PEREIRA, Mateus Henrique de Faria. Memória e Justiça nas Transições Políticas. Revista do Instituto de Hermenêutica Jurídica, vol. 8, p.36-51, 2011.

MARGALIT, Avishai. Letica della memoria. Bologna: Il Mulino, 2006.

MARTINS FILHO, João Roberto. A Guerra da Memória. Congresso da Associação de Estudos Latino-Americanos, Dallas, p.1-19, 2003.

NOBRE, Marcos. Imobilismo em movimento. São Paulo: Cia das Letras, 2013.

NOIRET, Serge. História digital pública. Liinc em Revista, vol. 11, p.28-51, 2015.

OLIVEIRA, Luciano. Ditadura militar, tortura e história. Revista Brasileira de Ciências Sociais, vol. 26, n. 75, p.7-25, 2011.

PASSERON, Jean-Claude; REVEL, Jacques. Penser par cas. Paris: EHESS, 2005. PEREIRA, Anthony W. Ditadura e repressão. São Paulo: Paz e Terra, 2010. PIERUCCI, Antônio Flávio. As bases da nova direita. Novos Estudos, n. 19, p.26-45, 1987.

POCHANN, Marcio. Desigualdade econômica no Brasil. São Paulo: Saber Livros, 2015.

PORTELLI, Alessandro. Lordine è già stato eseguito. Roma: Donzelli, 2005. PORTELLI, Alessandro. O massacre de Civitella Val do Chiana. In: FERREIRA, Marieta de Moraes; AMADO, Janaína (orgs.). Usos e abusos da história oral. Rio de Janeiro: FGV, 2000. p.103-130.

RANCIĖRE, Jacques. Entrevista a Flávia Natércia. Ciência e Cultura, vol. 57, p.16-17, 2005.

RANCIÈRE, Jacques. O ódio à democracia. São Paulo: Boitempo, 2014.

RANGEL, Marcelo de Mello; ARAUJO, Valdei Lopes de. Apresentação. História da Historiografia, vol. 17, p.318-332, 2015.

REIS, Daniel Aarão. Ditadura, anistia e reconciliação. Estudos Históricos, vol. 23, n.45, p.171-186, 2010. 
REIS, Daniel Aarão. Ditadura militar, esquerdas e sociedade. Rio de Janeiro: Zahar, 2000.

REVEL, Jaques (org.). Jogos de escalas. Rio de Janeiro: FGV, 1998.

RICOEUR, Paul. A memoria, a história, o esquecimento. Campinas: Unicamp, 2007.

RICOEUR, Paul. Du texto à l'action. Essais d'heméneutique II. Paris: Seuil, 1986.

RICOEUR, Paul. L'idéologie et l'utopie. Paris: Seuil, 1997.

RICOEUR, Paul. Le Juste 1. Paris: Ésprit, 1995.

RICOEUR, Paul. Percurso do reconhecimento. São Paulo: Loyola, 2006.

RODRIGUES, José Honório. Conciliação e Reforma no Brasil. Rio de Janeiro: Civilização Brasileira, 1965.

ROLLEMBERG, Denise. Esquecimento das memórias. In: MARTINS FILHO, João Roberto (org.). O golpe de 1964 e o regime militar. São Carlos: UFSCar, 2006. p.81-91.

ROSENZWEIG, Roy. Clio Wired. NewYork: Columbia, 2011.

SAFLATE, Vladimir Pinheiro. A esquerda que não teme dizer seu nome. São Paulo: Três Estrelas, 2012.

SAFATLE, Vladimir Pinheiro. Sobre o uso da violência contra o estado ilegal. In: TELES, Edson; SAFATLE, Vladimir Pinheiro (orgs.). O que resta da ditadura. São Paulo: Boitempo Editorial, 2010. p.245-278.

SARLO, Beatriz. Tempo passado. São Paulo: Cia das Letras, 2007.

SCHMIDT, Benito. Années de plomb. Cahiers d'Histoire, vol. 99, p.85-102, 2006.

SCHNEIDER, Nina. Breaking the "Silence" of the Military Regime. Bulletin of Latin American Research, vol. 30, n. 2, p.198-212, 2011.

SELIGMANN-SILVA, Márcio. Imagens precárias. Inscrições tênues da violência ditatorial no Brasil. Estudos de Literatura Brasileira Contemporânea, n. 43, p.13-34, 2014.

SILVA, Haike Roselane Kleber da (org.). A luta pela anistia. São Paulo: Unesp, 2009.

SOUZA, Jessé. A cegueira do debate brasileiro sobre as classes sociais. Interesse Nacional, vol. 7, p.35-47, 2014.

TEIXEIRA, Mauro Eustáquio. Revanche dos vencedores. Dissertação (Mestrado em História) - Universidade Federal de Ouro Preto. Ouro Preto, 2012. 
TELES, Edson; SAFATLE, Vladimir Pinheiro (orgs.). O que resta da ditadura. São Paulo: Boitempo Editorial, 2010.

VECCHI, Roberto. Barbárie e representação. In: PESAVENTO, Sandra Jatahy (org.). Fronteiras do milênio. Porto Alegre: Editora da UFRGS, 2001. p.71-94.

VECCHI, Roberto; DALCASTAGNÈ, Regina. Apresentação. Estudos de literatura brasileira contemporânea, n. 43, p.11-12, jan./jun. 2014.

VIDAL-NAQUET, Pierre. Los asesinos de la memoria. Madrid: Siglo Veintiuno, 1994.

VIRNO, Paolo. Saggio sulla negazione. Torino: Bollati Boringhieri, 2013. 